\section{Pecan Orchard Damage and Recovery from Ice Storms}

\author{
Michael W. Smith ${ }^{1,3,4}$ and Charles T. Rohla ${ }^{2}$
}

AdDitional Index wORDs. Carya illinoinensis, injury, limb breakage, economic, expense, cost, cleanup

SuMmARY. Typical damage, cleanup, and recovery from four ice storms beginning in Dec. 2000, with the latest in Dec. 2007, are reported for pecan (Carya illinoinensis). Damage levels were amplified as radial ice accretion increased. Cultivar affected the amount of damage incurred. Trees less than $15 \mathrm{ft}$ tall typically had the least damage. Trees 15 to $30 \mathrm{ft}$ tall incurred as much or more damage than larger trees and cleanup costs were greater. Production potential was directly related to canopy loss during the first growing season. The time to recover full production potential varied with the severity of canopy loss. Cleanup costs depended upon the amount of canopy damage incurred, tree spacing, tree size, and the amount of pruning needed to remove hanging and damaged limbs from the tree.

S evere weather events frequently have devastating impacts on perennial tree crops. Pecan orchards and groves are particularly susceptible to damage from tornadoes (Sparks and Payne, 1985), hurricanes (Hagler et al., 1980; Kilby and Converse, 1970; Reighard et al., 2001; Sparks, 2005; Wood et al., 2001), and ice storms (Lott and Ross, 1994; O'Barr, 1994; Smith, 2008). Ice damage is typically more severe in pecan orchards than other orchard crops because the long limbs act as levers, increasing the likelihood of breakage. Following damaging weather events, producers seek information concerning effective cleanup procedures, subsequent management, recovery duration, and economic impact. State and Federal agencies and insurance companies seek guidance concerning economic impact and how to assist producers. However, there is a dearth of information concerning management and economics following a destructive weather episode, particularly for ice storm damage, that is useful for pecan producers and supporting agencies.

Funding for this study was provided by the Oklahoma Agricultural Experiment Station.

Approved for publication by the Oklahoma Agricultural Experiment Station.

${ }^{1}$ Department of Horticulture and Landscape Architecture, Oklahoma State University, Stillwater, OK 74078

${ }^{2}$ Samuel Roberts Noble Foundation, Ardmore, OK 73402

${ }^{3}$ Regents Professor.

${ }^{4}$ Corresponding author. E-mail: mike.smith@okstate. edu.
Oklahoma has 85,740 acres of pecans on 2,879 farms (U.S. Department of Agriculture, 2002). About $90 \%$ of Oklahoma's production is from native groves, with the rest from planted orchards (Smith, 2006). Ice storms struck Oklahoma four times from 2000 through 2007. The first damaging storm was in Dec. 2000, followed by a storm in Dec. 2001, and then two icing events in 2007 during January and December. The Dec. 2000 ice storm encompassed the southeast quarter of Oklahoma, and extended into the northern parts of Texas and Louisiana and southwestern Arkansas. An estimated 25,000 to 30,000 acres of pecans were damaged in Oklahoma (Smith and Stafne, 2007). Damage varied among orchards depending primarily on the ice load, but in many instances, damage was severe (Fig. 1). The 2001 storm was in northwestern Oklahoma where there are few pecan orchards. Damage was extensive in some orchards, but not widespread. The Jan. 2007 ice storm followed U.S. highway 69 from southern Oklahoma extending through the Springfield, $\mathrm{MO}$, region (Smith and Stafne, 2007). An estimated 4,000 acres of pecans were damaged in Oklahoma. Some orchards received damage in both the Dec. 2000 and Jan. 2007 ice storms. The ice storm in Dec. 2007 received the most publicity because it included Tulsa, OK; Oklahoma City, $\mathrm{OK}$; and other highly populated areas. Damage from this storm extended from north central Texas, following a northeastern line through Oklahoma into Missouri. In Oklahoma, about 17,000 acres of pecans were damaged (Smith, 2008).

Our objective is to provide information for producers and others regarding the impact of an ice storm on pecans. Four ice storms covering a relatively short time span allowed numerous observations of orchard cleanup and subsequent management scenarios on tree performance. In addition, economic data are reported from selected producers.

\section{Observations}

ICE ACCRETION. Observations and producer reports indicated that the degree of damage to pecan was proportional to the amount of ice that accumulated on the trees, the cultivar, and tree size. There was little to no wind associated with each ice storm or while ice was on the trees. Damage would increase with the addition of stress caused by wind (Bruederle and Stearns, 1985; Hauer et al., 1994; Seischab et al., 1993). Proulx and Greene (2001) reported that the magnitude of ice accumulation on sugar maple (Acer saccharum), red maple (A. rubrum), quaking aspen (Populus tremuloides), and gray birch (Betula populifolia) was the primary determinant factor in tree damage when wind speed was modest $\left(\leq 26 \mathrm{~km} \cdot \mathrm{h}^{-1}\right)$, supportive of observations on pecan during four icing events. Damage was minimal until radial ice accretion was $\geq 20$ mm (Proulx and Greene, 2001). An ice storm in 1994 with up to 6 inches of ice reeked catastrophic damage to

\begin{tabular}{llll}
\hline $\begin{array}{l}\text { Units } \\
\begin{array}{l}\text { To convert U.S. to SI, } \\
\text { multiply by }\end{array}\end{array}$ & U.S. unit & SI unit & $\begin{array}{l}\text { To convert SI to U.S., } \\
\text { multiply by }\end{array}$ \\
\hline 0.4047 & acre(s) & $\mathrm{ha}$ & 2.4711 \\
0.3048 & $\mathrm{ft}$ & $\mathrm{m}$ & 3.2808 \\
0.7457 & horsepower & $\mathrm{kJ} \cdot \mathrm{s}^{-1}$ & 1.3410 \\
2.54 & inch(es) & $\mathrm{cm}$ & 0.3937 \\
25.4 & inch(es) & $\mathrm{mm}$ & 0.0394 \\
1.6093 & mph & $\mathrm{km} \cdot \mathrm{h}^{-1}$ & 0.6214
\end{tabular}



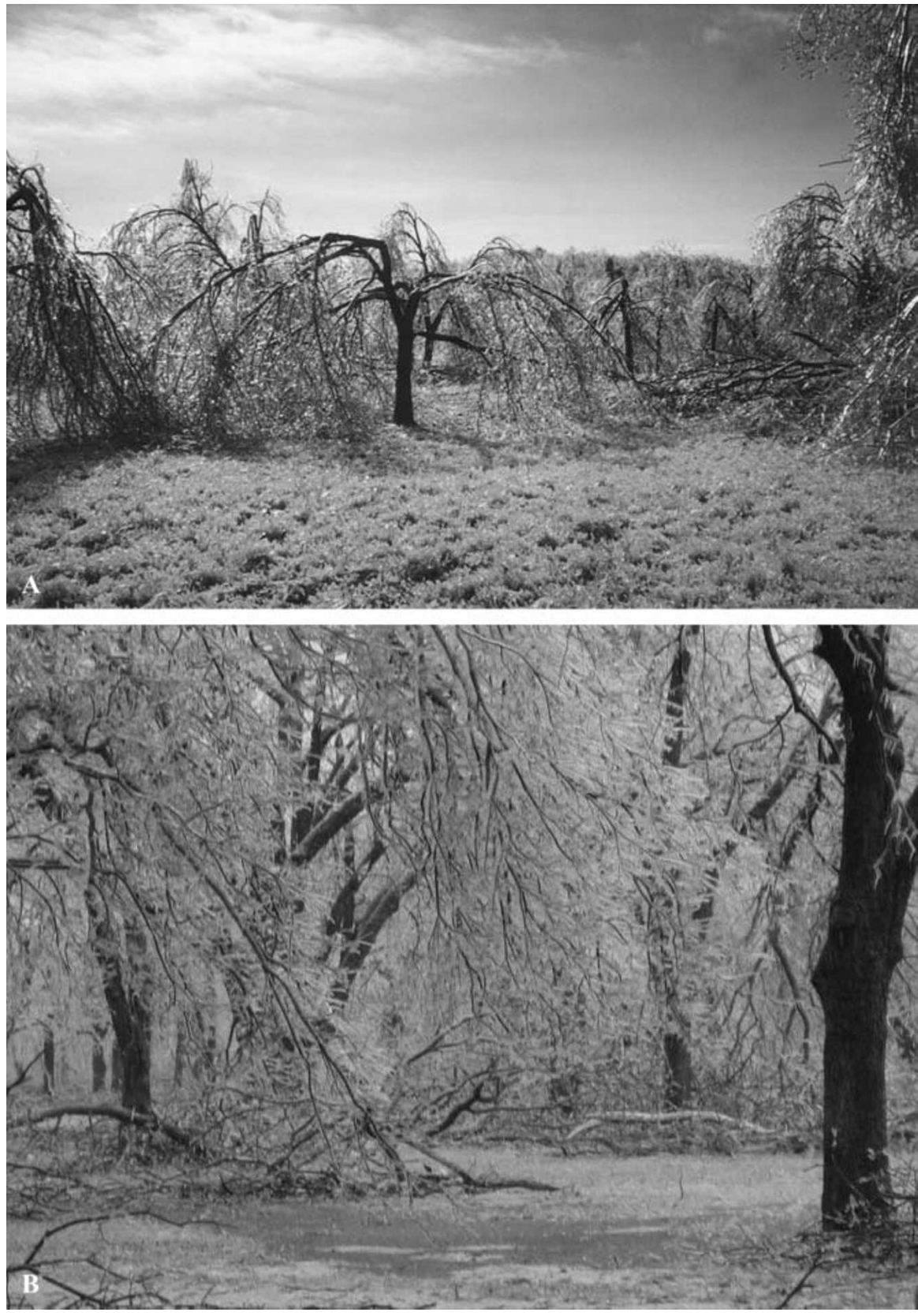

Fig. 1. Ice accretion in (A) a mixed native and cultivar pecan grove near Eufaula, $\mathrm{OK}$, in Dec. 2000, and (B) a native pecan grove near Skiatook, OK, in Dec. 2007.

Mississippi's pecan orchards (Lott and Ross, 1994).

Cultivar DifFerences. In pecan, damage was negligible on 'Kanza' and was moderate on 'Pawnee' trees that were 6- to 12 -years-old with radial ice accretion about 0.5 inch in Dec. 2007 (Fig. 2). There were about 400 trees of each cultivar in an orchard near Cleveland, OK. Only about $5 \%$ of the 'Kanza' trees had at least one $\geq 2$-inch limb broken, but $95 \%$ of the 'Pawnee' trees had one or more limbs $\geq 2$ inches broken. 'Pawnee' trees are more

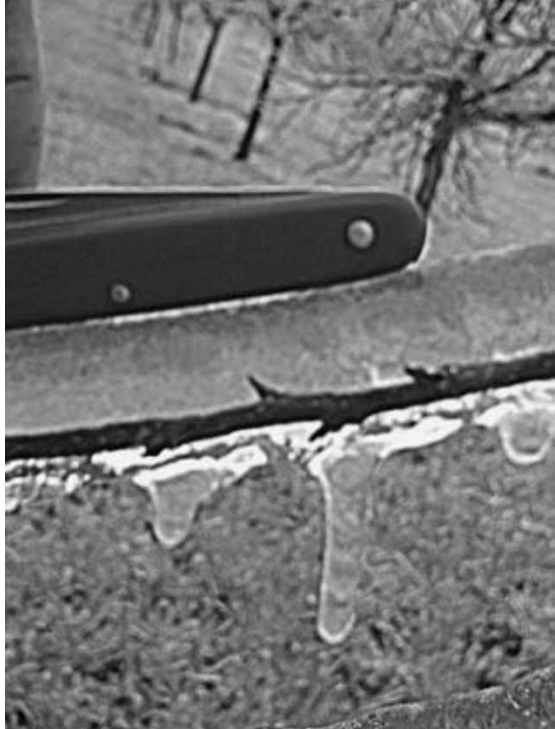

Fig. 2. Pecan limb with about $1 / 2$ inch $(12.7 \mathrm{~mm})$ radial ice accretion. The orchard is located near Cleveland, OK, and was damaged by the Dec. 2007 ice storm.

orchard, but limited observations indicated that the magnitude damage to 'Caddo' was similar to 'Pawnee' and the other cultivars were similar to 'Kanza' in the amount of damage sustained. O'Barr (1994) reported that 'Stuart' trees had more damage than 'Success' and 'Schley'. He attributed the difference to brittle wood on 'Stuart'.

Tree size. Pecan trees less than $15 \mathrm{ft}$ tall typically avoided major ice damage, but damage was severe on larger trees when the ice load was sufficient. Similarly, others reported that substantial branch loss primarily occurred on larger-sized trees in a forest, regardless of species (Proulx and Greene, 2001; Rhoads et al., 2002).

The greatest damage on pecan with the most expensive cleanup was on trees 15 to $30 \mathrm{ft}$ tall (Fig. 5). Limbs that broke typically reached the ground giving support that prevented them from breaking free of the tree. This necessitated that they be pruned for removal. In addition, when the limb was cut free, it frequently lodged in a crotch, necessitating that it be lifted for removal without additional tree damage. Taller trees, especially native pecan trees, were less time consuming to cleanup (Fig. 6). Limbs that broke usually fell to the ground rather than 

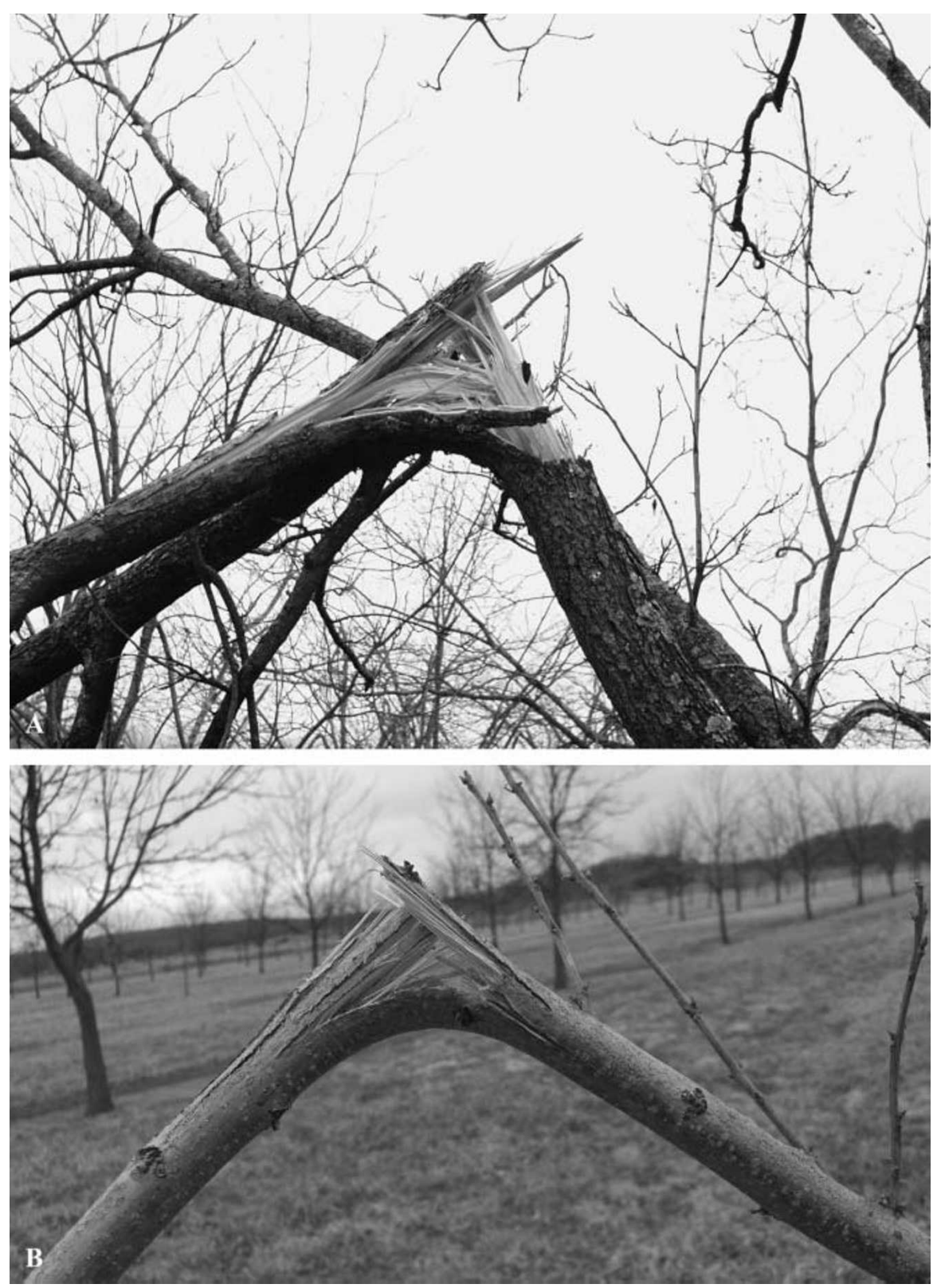

Fig. 3. Typical breaking pattern on (A) a 4-inch-diameter $(10.16 \mathrm{~cm})$ pecan limb and (B) 1 -inch-diameter $(2.54 \mathrm{~cm})$ pecan limb. Breaks typically occurred near the middle or basal portion of the limb, not at the point of attachment to the trunk or another limb.

hanging in the tree. Labor was required to remove hanging limbs, but there were far fewer than in the medium-sized trees.

Pecans are harvested by dislodging nuts with a trunk or limb shaker and then sweeping the nuts from the ground. Limbs that remain in the tree are a hazard to workers, particularly during harvest. Although expensive and time consuming, it is prudent to remove broken limbs that could cause personal injury and equipment damage.
When trees foliated, additional limb damage was apparent. Many limbs split longitudinally, but when the ice melted, the limbs returned to their prior position and the split was not apparent. However, the foliage weight bent the weakened limbs, making the damage visible. These limbs impeded orchard operations, requiring removal.

Tree survival. Pecan trees can sustain loss of their entire canopy and survive. Trees readily developed epicormic shoots when portions of the

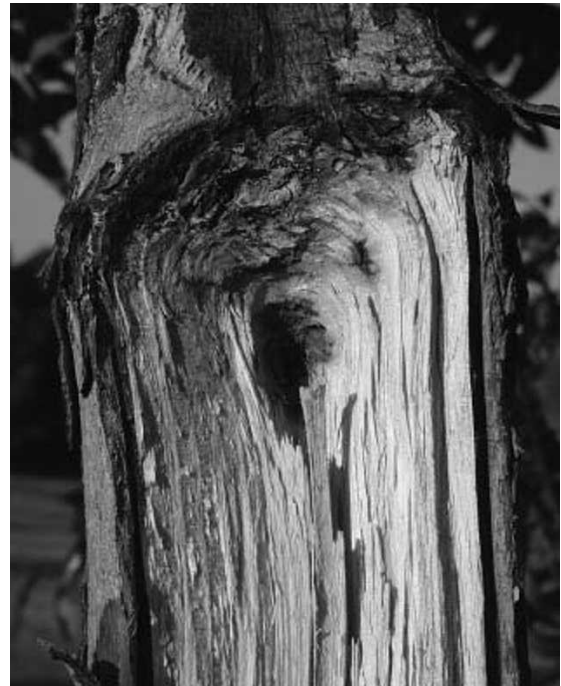

Fig. 4. Limb breakage at the crotch of 'Giles' pecan. Note the included bark substantially weakened the connection between the limb and trunk.

canopy were lost (Fig. 7). Shortle et al. (2003) studied five tree species with more than $75 \%$ crown loss caused by an ice storm. They found that species survival depended on the ability for rapid resprouting and vigorous growth that sustain trunk expansion combined with rapid canopy development. In a pecan transplanting study using trees with 12 - to 20-cm-diameter trunks, scaffold branches were stubbed back up to $100 \%$ (all branches removed from trunk) (Wood et al., 1990). Complete scaffold limb removal and transplanting with a tree spade resulted in only $8 \%$ mortality after 6 years. Shoot regrowth was proportional to the degree of pruning, and production was inversely proportional to the degree of canopy removed. Thus, pecan tree survival is probable, even when canopy loss exceeds $75 \%$, but production the following year will be proportionally decreased. Woodrotting organisms occasionally invade a tree at injury sites, weakening the tree and eventually making its removal necessary (O'Barr, 1994), but this has not appeared to be a major problem in observed pecan orchards. Unmanaged trees or those trees on sites that reduce tree vigor may suffer greater invasion of wood-rotting organisms.

Pruning. Pruning and cleanup are an enormous task following a major ice storm. Experience suggests that if the limb has fallen free from the tree, it is not economically feasible to 

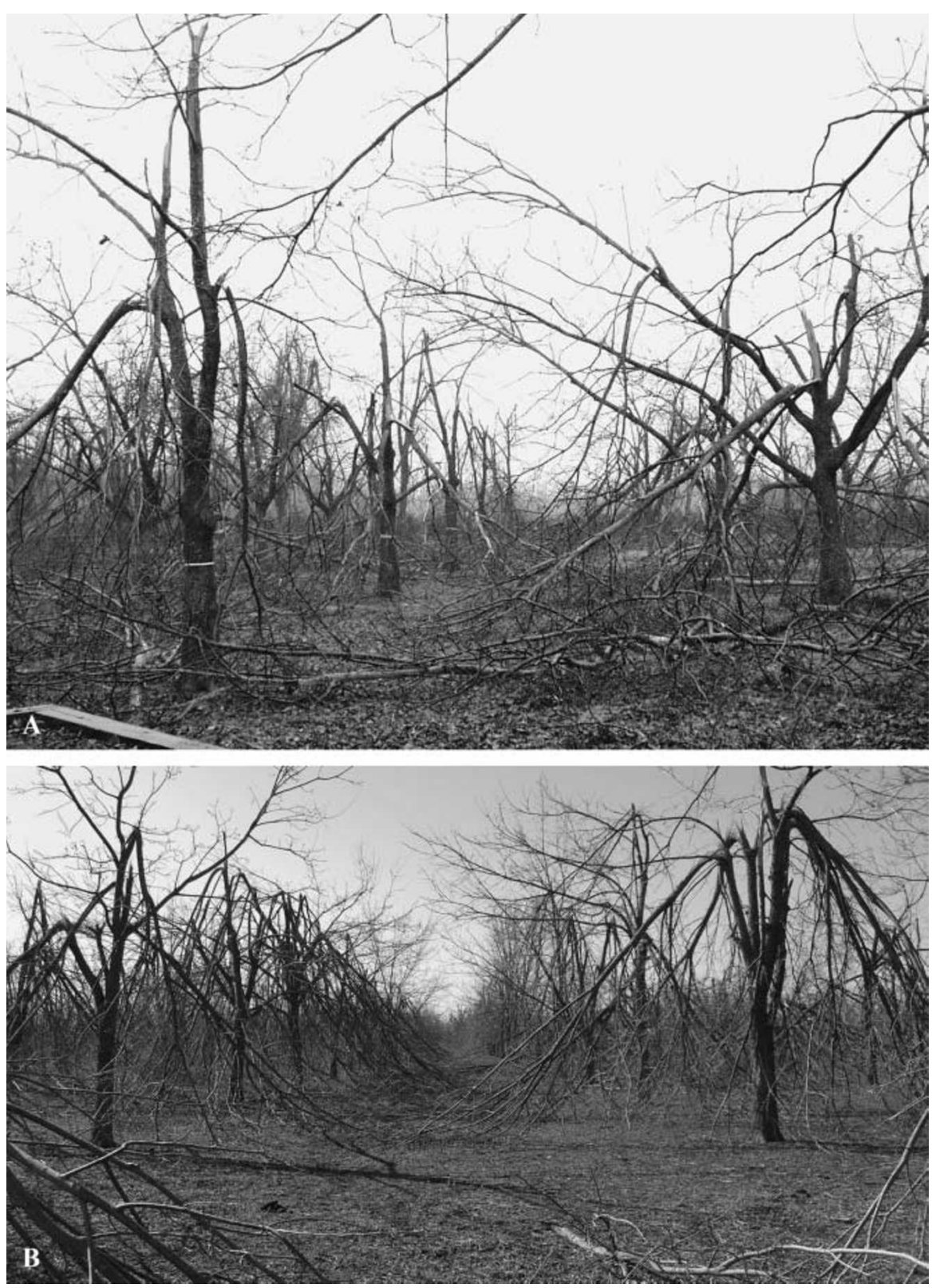

Fig. 5. Ice damage on (A) 'Choctaw' pecan trees from the Dec. 2000 ice storm at Idabel, OK, and on (B) 'Pawnee' from the Dec. 2007 ice storm near Skiatook, OK. Trees at Idabel were 30 to $40 \mathrm{ft}(9.1-12.2 \mathrm{~m})$ tall and at Skiatook trees were 20 to $30 \mathrm{ft}(6.1-9.1 \mathrm{~m})$ tall.

locate the jagged end of the limb and make a horticulturally desirable cut. Typically, those limbs wall-off the injured areas, resprout, and develop productive branches. Infection by wood-rotting organisms appeared similar whether left unpruned or pruned. Wood-rotting infections were reported to be more commonly associated with exceptionally large pruning cuts under humid conditions in Louisiana (O'Barr, 1994).

In those instances when the limb is retained in the tree and must be removed, typical thinning-out cuts should be used to reduce the number of epicormic shoots resulting from substantial canopy loss. Hence, broken limbs should be cut-off at a suitable lateral branch or the trunk. Limb removal at the trunk should leave the limb collar intact (Fig. 8). This reduces the size of the cut and the limb collar tends to impede wood-rotting organisms (Shigo, 1989).

Production. Pistillate flower induction occurs during the summer for next year's crop (Amling and Amling, 1983). Subsequent development of the pistillate flowers is modified by biotic and abiotic stress (Smith, 2005), but canopy damage from ice accretion had little or no effect on flower and fruit development the following growing season. The first growing season after ice damage, production was reduced in proportion to canopy loss (Table l). Subsequent year's yield reduction depended on the amount of canopy lost, orchard management, environmental conditions, and site adaptation.

Typically, the portion of the canopy that was not broken continued to be productive. In fact, branch loss tended to reduce the alternate bearing tendency (Smith, 2005) of the unbroken portion. Thus, after the first growing season, expected crop reduction was less than the canopy lost, unless canopy loss exceeded $90 \%$ (Table 1). Canopy loss of $90 \%$ or more resulted in vigorous vegetative growth with little, if any, production until the fifth year following the damage. The exception was trees smaller than $25 \mathrm{ft}$ tall that lost more than $50 \%$ of their canopy, which tended to become excessively vegetative with little production for about 3 years. The compensatory growth that results from canopy loss was extremely vigorous (Fig. 7), and typically not productive for at least 3 years. Normally, in well-managed orchards, epicormic shoot growth was vertical and rapid the first year. The second year, growth remained vigorous and upright with some lateral branches developing on the compensatory shoots, particularly if canopy loss did not exceed about $40 \%$. The third year, flowers and fruit were borne on some of the lateral branches that developed during the second year on the compensatory shoots. Growth remained upright and vigorous, and more lateral branches developed, gradually returning to a productive canopy. Development of lateral branches and production was delayed on the epicormic shoots as canopy loss increased.

Nitrogen $(\mathrm{N})$ and zinc $(\mathrm{Zn})$ fertilization were major factors affecting recovery of production potential. In particular, $\mathrm{N}$ fertilization had to be balanced to avoid excessive growth that was susceptible to wind damage and unable to support subsequent crops. Too much $\mathrm{N}$ fertilization 

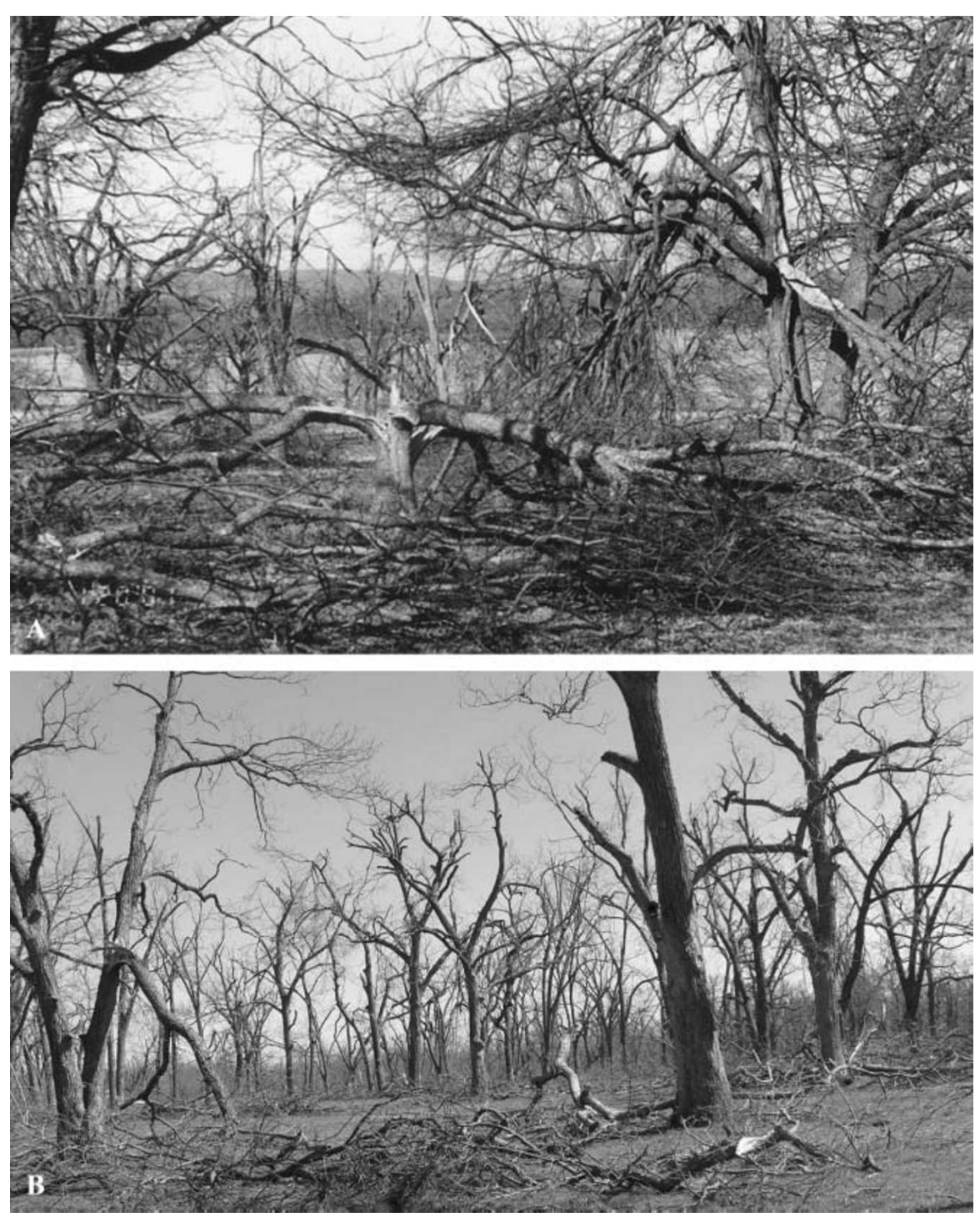

Fig. 6. Ice damage to (A) a mixed native and cultivar pecan orchard near Eufaula, OK, damaged in Dec. 2000, and (B) a native pecan orchard near Skiatook, OK, damaged Dec. 2007. Trees in A are native trees and cultivars, primarily 'Maramec', grafted onto native pecan rootstocks. Trees pictured were 40 to $60 \mathrm{ft}(12.2-18.3 \mathrm{~m})$ tall. Trees pictured in $B$ are about $60 \mathrm{ft}$ tall.

produced undue upright growth with few lateral branches, thus delaying recovery of production potential. Withholding N reduced shoot growth, postponing canopy recovery and could increase susceptibility to cold injury (Smith and Cotten, 1985). Orchard site characteristics (soil type, surface and internal soil drainage, irrigation, tree crowding, groundcover type and management, double cropping with livestock) and the amount of canopy lost were the two most important factors determining optimum nitrogen rate.

In areas of Oklahoma where $\mathrm{Zn}$ is deficient, the vigorous epicormic shoots usually required five foliar applications of $\mathrm{Zn}$ at 2-week intervals two to three applications are sufficient for bearing trees, but the vigorous growth and longer growing period required additional $\mathrm{Zn}$ applications. Inadequate $\mathrm{Zn}$ application reduced growth, delaying canopy recovery.

\section{Cost of cleanup}

Eufaula orchard. Cleanup costs are reported for a 250-acre orchard located near Eufaula, OK, that sustained damage in the Dec. 2000 storm, and again in the Jan. 2007 storm. The orchard was composed of $85 \%$ native pecan trees and $15 \%$ cultivars, primarily 'Maramec', beginning at budbreak. Normally, grafted onto native pecan rootstocks. Tree size and spacing were variable, ranging from young seedlings to 60 $\mathrm{ft}$-tall trees, with a mean tree density of 25 trees/acre. Loss of canopy from the Dec. 2000 storm was $\approx 50 \%$ and $35 \%$ in Jan. 2007. Damage in 2000 consisted of limb breakage and split limb crotches described earlier. In 2007, about one-half of the debris was from compensatory shoots 3 to 4 inches in diameter that were 15 to 20 $\mathrm{ft}$ long. The rest of the debris was from other limb and crotch damage.

Equipment used to cleanup from the 2000 storm included a $25-\mathrm{ft}$ lift equipped with a hydraulic pole chain saw, a bulldozer (450C; John Deere, Moline, IL), an 18 - $\mathrm{ft}$ limb rake (Savage Equipment, Madill, OK), two gas-powered pole chain saws, a chain saw, a 65-horsepower tractor, a 105horsepower tractor, a flat bed dump trailer, and a 1 -ton truck. In 2007, equipment remained the same, except that the lift was not used and a 65horsepower tractor equipped with a grapple fork was added.

In 2000, 4320 man-hours were required to clean the 250 -acre orchard. Therefore, the labor requirement was $17 \mathrm{~h} /$ acre or about $0.75 \mathrm{~h} /$ tree. The producer's cost of cleanup was $\$ 250 /$ acre in 2000 . Adjustment based on the consumer price index indicates this is equivalent to $\$ 311.88 /$ acre in 2008 (U.S. Bureau of Labor Statistics, 2008). In 2007, 3024 h of labor were needed to prune and remove debris from the orchard, with a total cleanup cost of $\$ 200 /$ acre (\$207.22/acre in 2008). Additional expense associated with the ice storms not included in the cost estimate was removal of ice-damaged limbs not apparent until foliated, and extra labor needed during harvest to remove debris before using the harvester. The producer reported that two additional people were required to pick up limbs while harvesting.

Dec. 2007 ICE storm. The cleanup cost is available for two orchards from the Dec. 2007 storm, one located at Skiatook and the other at Collinsville, both managed by the same individual. Equipment used to cleanup these orchards included two lifts equipped with hydraulic pole chainsaws. One had a maximum height to the platform of $60 \mathrm{ft}$ and was expensed at $\$ 18 / \mathrm{h}$; the other was $25 \mathrm{ft}$ tall and expensed at $\$ 15 / \mathrm{h}$. A 

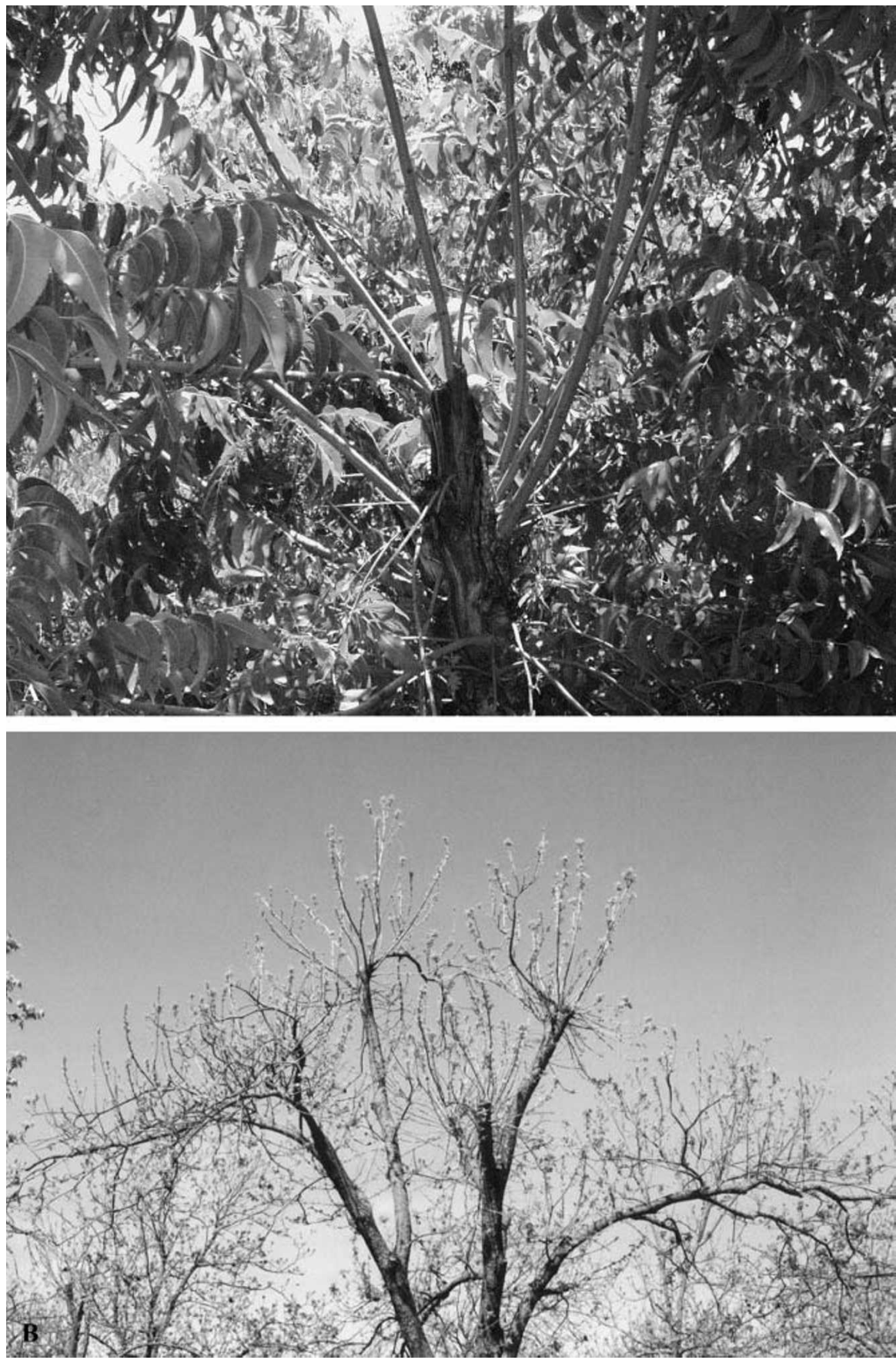

Fig. 7. (A) 'Kiowa' pecan tree near Idabel, $\mathrm{OK}$, with 15 vigorous sprouts arising near the broken end of a limb about 3 inches $(7.62 \mathrm{~cm})$ in diameter at the break. Note that the break was left jagged. The photograph was taken during the Spring of the second growing season following the Dec. 2000 ice storm. (B) Native pecan tree near Eufaula, OK, showing numerous sprouts during the spring of the second growing season following the Dec. 2000 ice storm.

skid loader equipped with a grapple bucket was expensed at $\$ 16 / \mathrm{h}$. Other equipment included 80-horsepower tractor, equipped with an 18 -ft-wide brush rake (Savage Equipment) and a front-end loader at $\$ 25 / \mathrm{h}$, a bulldozer (D-6; Caterpillar, Peoria, IL) at $\$ 80 / \mathrm{h}$, an all terrain vehicle $(\mathrm{ATV})$ at $\$ 3 / \mathrm{h}$, and a chainsaw expensed at $\$ 1 /$ h. A 1 -ton truck was used to transport men and equipment to and from the site, obtain repair parts, and other errands. The reimbursement rate was $\$ 0.505 / \mathrm{mile}$. The fuel and oil expenses were excluded because they were included in the mileage

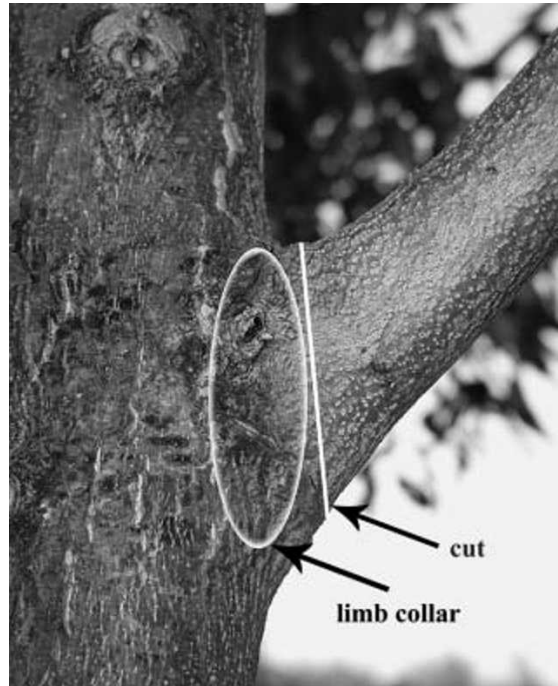

Fig. 8. The line indicates where a pruning cut should be made on pecan to leave the limb collar intact (oval).

charge. Employees varied from three to seven individuals, depending on availability. They were paid $\$ 9$ or $\$ 15$ per hour, depending on their skill. Taxes paid on wages were $7.5 \%$ and were added to the labor charge. The owner served as supervisor, and his labor was not included in the cleanup costs. Workers' compensation insurance was carried for all employees and is listed separately from their salary.

Cleanup began following the December ice storm with most of the work accomplished by the end of April. The producer noted that the tractor and rake combination was effective and rapid for moderately sized brush while the groundcover was short. However, when the groundcover was tall, the rake was no longer useful in removing debris, and cleanup costs increased.

SKIATOOK ORCHARD. This orchard includes 200 acres of pecan trees. The 'Pawnee' portion was 90 acres (Fig. 5B) and native pecan trees constituted the remainder of the 200 acres (Fig. 6B). 'Pawnee' trees were spaced $35 \times 35 \mathrm{ft}$ (35.5 trees/ acre). Native trees were irregularly spaced and ranged from 12 to 20 trees/acre. Canopy loss in the 'Pawnee' trees was estimated at $80 \%$ to $90 \%$ and in the native trees was estimated at $60 \%$ to $80 \%$. Substantially more labor was needed to prune and cleanup the 25- to 30-ft-tall 'Pawnee' trees compared with the 40 - to 
Table 1. Observations of pecan production potential relative to expected production without ice damage. Observations represent the range in response observed from various levels of management and site suitability for trees older than 15 years.

\begin{tabular}{lcccc}
\hline \multirow{2}{*}{$\begin{array}{l}\text { Growing } \\
\text { season following } \\
\text { damage (no.) }\end{array}$} & \multicolumn{4}{c}{ Expected crop reduction } \\
\cline { 2 - 5 } Canopy loss (\%) \\
\hline 1 & $\mathbf{0}$ to $\mathbf{2 0}$ & $>\mathbf{2 0}$ and $\leq \mathbf{5 0}$ & $\mathbf{5 0}$ and $\leq \mathbf{7 5}$ & $>\mathbf{7 5}$ \\
2 & 0 to 20 & $20-50$ & $50-75$ & $75-100$ \\
3 & 0 & $10-30$ & $30-60$ & $60-100$ \\
4 & 0 & $10-20$ & $20-60$ & $60-100$ \\
5 & 0 & $0-20$ & $20-50$ & $50-100$ \\
6 & 0 & $0-10$ & $10-30$ & $30-80$ \\
7 & 0 & 0 & $0-20$ & $20-50$ \\
8 & 0 & 0 & 0 & $0-20$ \\
\hline
\end{tabular}

Table 2. Cleanup expenses in 2008 at a 200 -acre (80.9 ha) 'Pawnee' and native pecan orchard near Skiatook, OK.

\begin{tabular}{lcr}
\hline Expense item & $\begin{array}{c}\text { Time } \\
(\mathbf{h} / \text { acre })^{\mathbf{z}}\end{array}$ & $\begin{array}{c}\text { Cost } \\
(\mathbf{\$} / \mathbf{a c r e})^{\mathbf{y}}\end{array}$ \\
\hline Labor & 11.1 & 136.55 \\
Lift & 3.7 & 61.22 \\
Skid loader (Bobcat, West Fargo, ND) & 2.0 & 63.64 \\
80-horsepower $\left(59.7 \mathrm{~kJ} \cdot \mathrm{s}^{-1}\right)$ tractor and & & 36.09 \\
$\quad$ 18-ft $(5.5 \mathrm{~m})$ rake & 1.4 & 64.20 \\
Bulldozer $(\mathrm{D}-6$; Caterpillar, Peoria, IL) & 0.8 & 2.54 \\
All terrain vehicle & 0.8 & 0.50 \\
Chain saw & 0.5 & 0.18 \\
l-ton $(0.9 \mathrm{Mg})$ truck, 70 miles $(112.7 \mathrm{~km})$ & & 37.23 \\
$\quad$ at $\$ 0.505 /$ mile $(\$ 0.3138 / \mathrm{km})$ & - & 14.10 \\
Fuel and oil & - & 3.67 \\
Repairs & - & 419.92 \\
Workers' compensation insurance & - & \\
Total & - & \\
\hline
\end{tabular}

${ }^{2} 1 \mathrm{~h} /$ acre $=2.4711 \mathrm{~h} \cdot \mathrm{ha}^{-1}$.

甲 $\$ 1.00 /$ acre $=\$ 2.4711 / \mathrm{ha}$.

Table 3. Cleanup expenses in 2008 at a 229 -acre (92.7 ha) native pecan orchard near Collinsville, OK.

\begin{tabular}{lcr}
\hline Expense item & $\begin{array}{c}\text { Time } \\
(\mathbf{h} / \text { acre })^{\mathbf{z}}\end{array}$ & $\begin{array}{c}\text { Cost } \\
(\mathbf{\$} / \mathbf{a c r e})^{\mathbf{y}}\end{array}$ \\
\hline Labor & 8.2 & 99.44 \\
Lift & 1.9 & 33.73 \\
Skid loader (Bobcat, West Fargo, ND) & 1.1 & 17.23 \\
80-horsepower $\left(59.7 \mathrm{~kJ} \cdot \mathrm{s}^{-1}\right)$ tractor and & & \\
$\quad 18$-ft $(5.5 \mathrm{~m})$ rake & 1.3 & 20.80 \\
Bulldozer $(\mathrm{D}-6$; Caterpillar, Peoria, IL) & 0.7 & 38.64 \\
All terrain vehicle & 1.2 & 3.73 \\
Chain saw & 0.7 & 0.70 \\
l-ton $(0.9 \mathrm{Mg})$ truck, 1200 miles $(1931.2 \mathrm{~km})$ & & 2.65 \\
$\quad$ at $\$ 0.505 /$ mile $(\$ 0.3138 / \mathrm{km})$ & - & 37.23 \\
Fuel and oil & - & 13.89 \\
Repairs & - & 3.67 \\
Workers compensation insurance & - & 271.71 \\
Total & - &
\end{tabular}

${ }^{2} 1 \mathrm{~h} /$ acre $=2.4711 \mathrm{~h} \cdot \mathrm{ha}^{-1}$.

y $\$ 1.00 /$ acre $=\$ 2.4711 / \mathrm{ha}$.
70 -ft-tall native trees; however, the producer records reflected expenses by orchard, not tree type (Table 2 ). The number of hours for the lift was also substantially higher for the 'Pawnee' trees because most of the broken limbs had to be cut from the tree, rather than falling free as was usually the case for the native trees. In addition, limbs cut from the 'Pawnee' trees frequently fell in the crotches, necessitating that they be lifted and slid sideways for removal to avoid additional damage. The greater tree density in the 'Pawnee' orchard made debris removal more time consuming because it had to be moved around the trees without damaging the trunks.

Collinsville ORCHARD. The Collinsville orchard includes 220 acres of native pecan trees. Most of the trees were 50 to $60 \mathrm{ft}$ tall, ranging in density from 12 to 20 trees/acre. Expenses reflect canopy loss of $60 \%$ to $80 \%$, with the majority of the limbs falling free from the tree (Table 3 ). Hanging limbs were pruned from the tree. The large difference in costs at Collinsville vs. Skiatook (Table 2) reflects the additional time required in the 'Pawnee' trees.

\section{Conclusions}

Ice storms are one of many weather-related risks associated with production of perennial tree crops. Major storms occur at least once per decade and truly catastrophic icing events once or twice a century within a broad belt extending from eastern Texas through New England (Ireland, 2000). Pecan trees are resilient, surviving and eventually returning to productivity following loss of most of the crown. Cleanup costs ranged from $\$ 207 /$ acre to $\$ 419 /$ acre based on the dollar value in 2008. These costs reflect orchards where the owner supervised the labor and had the necessary resources to obtain sufficient equipment to efficiently prune and remove debris from the orchard. In neither case was a charge added for the owner's supervision. Custom operators renovating orchards following an ice storm were more expensive, typically charging $\$ 500 /$ acre to $\$ 800$ /acre in 2008 for orchards with similar damage levels reported at Skiatook and Collinsville.

Trees continue to produce pecans on the undamaged portion of 
their canopy unless the trees are small and severely damaged. Three years or longer were required for epicormic shoots to become productive. The time to regain full production was dependent upon the amount of canopy lost, orchard management, orchard site characteristics, cultivar, and subsequent weather events.

\section{Literature cited}

Amling, H.J. and K.A. Amling. 1983. Physiological differentiation of pistillate flowers of pecan and cold requirements for their initiation. J. Amer. Soc. Hort. Sci. 108:195-198.

Bruederle, L.P. and F.W. Stearns. 1985. Ice storm damage to a southern Wisconsin mesic forest. Bull. Torrey Bot. Club 112:167-175.

Hagler, T.B., J.L. Boutwell, and L. Johnson. 1980. Damage to pecans in Alabama by hurricane Frederic. Proc. Southeastern Pecan Growers' Assn. 73:99-105.

Hauer, R.J., M.C. Hruska, and J.O. Dawson. 1994. Trees and ice storms: The development of ice storm-resistant urban tree populations. Dept. Forestry, Univ. Illinois Urbana-Champaign Spec. Publ. 94-1.

Ireland, L.C. 2000. Ice storms and forest impacts. Sci. Total Environ. 262:231-242.

Kilby, W.W. and R.B. Converse. 1970. Hurricane Camille damage to pecans in Mississippi. Southeastern Pecan Growers'. Assn. 63:120-128.
Lott, N. and T. Ross. 1994. 1994 Weather in the Southeast. 3 June 2008. <http://wwwl.ncdc.noaa.gov/pub/ data/techrpts/tr9403/tr9403.pdf>.

O'Barr, R.D. 1994. Ice storm inflicts tree damage in several states. Pecan South 27(1):7-8,15,22.

Proulx, O.J. and D.F. Greene. 2001. The relationship between ice thickness and northern hardwood tree damage during ice storms. Can. J. For. Res. 31:17581767.

Reighard, G.L., M.L. Parker, G.W. Krewer, T.G. Beckman, B.W. Wood, J.E. Smith, and J. Whiddon. 2001. Impact of hurricanes on peach and pecan orchards in southeastern United States. HortScience 36:250-252.

Rhoads, A.G., S.P. Hamburg, T.J. Fahey, T.G. Siccama, E.N. Hane, J. Battles, C. Cogbill, J. Randall, and G. Wilson. 2002. Effects of an intense ice storm on the structure of a northern hardwood forest. Can. J. For. Res. 32:17631775 .

Seischab, F.K., J.M. Bernard, and M.D. Eberle. 1993. Glaze storm damage to western New York forest communities. Bull. Torrey Bot. Club 120:64-72.

Shigo, A.L. 1989. A new tree biology: Facts, photos, and philosophies on trees and their problems and proper care. Shigo and Trees Assoc., Snohomish, WA.

Shortle, W.C., K.T. Smith, and K.R. Dudzik. 2003. Tree survival and growth following ice storm injury. U.S. Dept. Agr., For. Serv. Res. Paper NE-723 .
Smith, M.W. 2005. Understanding alternate bearing. Pecan South 38(10):32-37.

Smith, M.W. 2006. Pecan statistics. Oklahoma Pecan Growers' Assn. Nwsl. 47(3): 5-8.

Smith, M.W. 2008. Oklahoma's 2nd ice storm in 2007. Oklahoma Pecan Growers' Assn. Nwsl. 49(1):1-2.

Smith, M.W. and B.C. Cotten. 1985. Relationship of leaf elemental concentrations and yield to cold damage of 'Western' pecan. HortScience 20:442-445.

Smith, M.W. and E. Stafne. 2007. Oklahoma's 2007 ice damage. Oklahoma Pecan Growers Assn. Nwsl. 48:(1)8.

Sparks, D. 2005. Tree setting depth affects wind resistance in pecan. J. Amer. Pomol. Soc. 59:134-140.

Sparks, D. and J.A. Payne. 1985. 'Schley' vs. 'Stuart': 'Schley' sustains more tornado damage. Pecan South 19(6):10.

Wood, B.W., J.A. Payne, and O. Jones. 1990. Transplanting bearing pecan trees. HortScience 28:916-918.

Wood, B.W., W. Goff, and M. Nesbitt. 2001. Pecans and hurricanes. HortScience 36:253-258.

U.S. Bureau of Labor Statistics. 2008. Inflation calculator. 30 May 2008. <http:// data.bls.gov/cgi-bin/cpicalc.pl>.

U.S. Department of Agriculture. 2002. Census of agriculture. 20 May 2008. <http://www.nass.usda.gov/Census/ Pull_Data_Census>. 